\title{
Istorijos muziejus: samprata, šiuolaikinių muziejinių naratyvų kūrimo idèjos ir jų raiška Vilniaus mieste
}

\author{
RŪTA ŠERMUKŠNYTÉ \\ Vilniaus universitetas, Istorijos fakultetas, Universiteto g. 7, LT-01513 Vilnius \\ El. paštas: ruta.sermuksnyte@if.vu.It
}

\begin{abstract}
Straipsniu siekiama suaktualinti nūdienos Lietuvoje pagyvèjusiose istorinès kultūros / atminties studijose kiek nuošalèje paliktą klausimą: kokias istorines ir kultūrines orientacijas istorijos muziejus teikia savo muziejiniais naratyvais? Išsikelto tikslo igyvendinimas lemia šio straipsnio dvilypumą: orientaciją $\mathfrak{t}$ apibendrinimus ir konkretaus atvejo analizę. Užsienio ir lietuvių muzeologiniai tyrimai pasitelkiami apsibrèžti pakitusią istorijos muziejaus sampratą, atskleisti istorijos muziejaus kaip istorinès kultūros formos specifiką bei išsiaiškinti šiuolaikinių muziejinių pasakojimų kūrimo idejjas. Remiantis jais atliekamas muziejinių naratyvų istorijos Vilniaus muziejuose tyrimas. Tokio pobūdžio tyrimams Vilnius yra parankus kaip tankiausią muziejų tinklą Lietuvoje turintis miestas, o tai savo ruožtu reiškia įvairių muziejinių naratyvų galimybę. Tyrimas, paremtas šio miesto muziejuose pastaraisiais metais veikusių ir nūnai tebeveikiančių parodų bei ekspozicijų analize, orientuotas ne į visų muziejinių pasakojimų variantų ịvardijimą, o esminių tendencijų (vyraujančių ir alternatyvių) atskleidimą.
\end{abstract}

Raktažodžiai: istorijos muziejus, istorinė sąmonė, istorinẻ kultūra, muziejinis naratyvas, Vilnius

\section{IVADAS}

2012-ieji - Dionizo Poškos Baublių 200 metų sukakties metai - paskelbti muziejų metais. Tai, kad Lietuvos Respublikos Seimas pirmuoju viešuoju muziejumi Lietuvoje traktuoja 1812 m. ̨̇kurtus Baublius [24] (neabejotinai reikšmingus kaip etnografijos muziejaus pirmtaką bei tautos muziejaus užuomazgas), o ne $1752 \mathrm{~m}$. Vilniaus universitete ịsteigtą scientistinio pobūdžio Matematikos muziejų [plačiau 17, 38-41], greičiausiai liudija ne Lietuvos muziejų istorijos neišmanymą, o istorijos muziejaus svarbos Lietuvos kultūroje akcentavimą. Nei Lietuvoje, nei už jos ribų neabejojama, kad tautos praeitị bei dabartị reprezentuojantis muziejus yra vienas iš tam tikrų bendruomenių (valstybès, tautos, vietos ir t. t.) identitetą formuojančių, ịtvirtinančių ir reprezentuojančių veiksnių. Tačiau nūdienos Lietuvoje 
pagyvejjusiose istorinès kultūros / atminties studijose (1) trūksta ženklesnio istorijos muziejaus kaip istorinès kultūros instancijos ịvertinimo (išimtini laikytini Rasos Čepaitienès [8], Dangiro Mačiulio [26], Birutès Salatkienès [37] tyrimai), tikètina, sąlygoto skurdžių lietuviškų muzeologinių tyrimų (2). Tai suaktualina mokslinę diskusiją apie Lietuvos muziejų kaip kultūros paveldo saugotojų, tyrèjų ir perteikẻjų vaidmenị istorinèje kultūroje. Trečiasis, t. y. komunikacinis, muziejinès veiklos dėmuo patenka ị moderniosios istorijos didaktikos, tiriančios istorinès sąmonès, istorinès kultūros ir istorijos perteikimo klausimus, rèmus. I istorijos didaktikos programą istorijos muziejus ịsiterpia kaip viena iš istorinès sąmonès formavimo ir performavimo (vykstančių dèka istorijos perteikimo muziejiniuose naratyvuose) instancijų, kurioje juntamas visuomenès istorinès sąmonės „pulsas“ (3).

Siekiant ịvertinti istorijos muziejų kaip istorinès sąmonès veiksnị, pirmiausia būtina atsakyti $\mathfrak{i}$ klausimą: kokias istorines ir kultūrines orientacijas jis teikia savo muziejiniais naratyvais, t. y. i prasmingas visumas susietais ekspozicijos elementais? Šis straipsnis ir yra skirtas atsakymo i pateiktą klausimą paieškoms. Išsikelto tikslo igyvendinimui būtini konceptualūs rẻmai, kurių nustatymas lemia šio straipsnio dvilypumą: orientaciją i apibendrinimus ir konkretaus atvejo analizę. Užsienio (Gaynor Kavanagh [15-16], Friedricho Waidacherio [44], Berndo Reses [33] ir kt.) ir lietuvių (Anastazijos Keršytės [17-20], Žyginto Būčio [3-4]) muzeologiniai tyrimai pasitelkiami apsibrèžti pakitusią istorijos muziejaus sampratą (I skyrius), atskleisti istorijos muziejaus kaip istorinès kultūros formos specifiką (II skyrius) bei išsiaiškinti šiuolaikinių muziejinių pasakojimų kūrimo idẻjas (III skyrius). Nustatę, kas laikytina istorijos muziejumi, kaip jame kuriami muziejiniai naratyvai ir kaip jie gali būti vertinami, atliekama muziejinių naratyvų istorijos Vilniaus muziejuose analizè (IV skyrius), kuri paremta šio miesto muziejuose pastaraisiais metais veikusių ir nūnai tebeveikiančių parodų bei ekspozicijų analize. Šiuo straipsniu nesiekiama ịvardyti visų muziejinių pasakojimų variantų, o veikiau susitelkiama ties esminèmis (vyraujančiomis ir alternatyviomis) tendencijomis. Vilniaus muziejinè kultūra atvejo analizei pasirinkta dẻl kelių priežasčių. Pirma, tokio pobūdžio tyrimams Vilnius yra parankus kaip tankiausią muziejų tinklą Lietuvoje turintis miestas, ir tai užtikrina ịvairių muziejinių naratyvų galimybę. Antra, ligšiolinèse istorinès kultūros / atminties studijose aktualizuojant daugiakultūrị Vilniaus paveldą nuošalèje paliekamas ịvairias istorines epochas siekiantis šio miesto muziejinių pasakojimų „raizginys“. I turtingą sostinès muziejų kultūrą jau yra atkreipusi demesị lietuvių muzeologė Nastazija Keršytė [20], atlikdama Vilniaus muziejų, kaip miesto atminties reprezentantų, lyginamąją analizę.

\section{ISTORIJOS MUZIEJAUS SAMPRATA}

$\mathrm{XX}$ a. paskutiniaisiais dešimtmečiais pastebima istorijos muziejaus sampratos kaita. Britu muzeologė Gaynor Kavanagh, itin daug dėmesio skirianti istorijos muziejams, 1990 m. teigè [16, 3], kad apibrèžti sąvoką „istorijos muziejus“ (angl. History Museum) yra taip pat

(1) Kaip vieni reprezentatyviausių tyrimų paminètini R. R. Trimonienès, R. Jurgaičio [23], A. Bumblausko [29] bei A. Nikžentaičio [32] sudaryti veikalai.

(2) Plačiau apie muzeologijos tyrimus Lietuvoje žr. [19].

(3) Antai moderniosios istorijos didaktikos programos idejjas realizuojančio vokiečių muzeologo B. Reses modelyje siūloma sujungti šios istorijos didaktikos svarstomus klausimus ir muziejinio perteikimo problematiką ir tyrinèti kaip muzeologijos didaktikos (vok. Museologiedidaktik) teoriją. Muzeologijos didaktikos objektu siūloma ne istorinė sąmoné, bet kultūros sąmonė arba kultūrinis identitetas. B. Rese šią tyrimo objektų kaitą grindžia teiginiu, kad visuomenei èmus sąveikauti su materialiuoju palikimu ir ji paverčiant paveldu, susiklosto santykis ne tiek su istorija, kiek su kultūra [plačiau 33, 159-172; taip pat žr. 40, 17-19]. 
sunku, kaip ir nusakyti, kas yra „istorija muziejuose“. Net dvyliką iš keturiolikos medžiaginių kolekcijų rūšių, aptinkamų Didžiosios Britanijos muziejuose (vaizduojamasis menas, dekoratyvinis menas, mokslas, industrinè archeologija, technologija ir transportas, jūrų istorija, socialinè kaimo istorija, socialinè miesto istorija, archeologija ir etnologija, muzika, architektūra, karinè ir civilinė tarnyba), galima, britų muzeologès teigimu [16, 3], îvardyti istorinèmis. 1990 m. vokiečių muzeologai Gotfriedas Korffas ir Martinas Rothas [21, 7] tvirtino, kad istorijos muziejus (vok. das historische Museum) apima muziejų tipų, formų, rūšių ịvairovę: politinès istorijos, miesto ir kultūros istorijos, kraštotyros ir bendruomenių, ìvairius muziejus po atviru dangumi, technikos ir mokslo istorijos, civilizacijų istorijos, meno istorijos ir t. t. Minèti teiginiai rodo, kad istorijos muziejais laikomi nebe istorijos profilio muziejai (šalia kultūros istorijos, etnografijos, archeologijos, meno, technikos ir mokslo, gamtos ir kitų muziejų, klasifikuojamų pagal jų ryšį su tam tikra disciplina [žr. pvz., 50, 333-336; 44, 222-227]), o visi, kurie pasitelkdami muziejinius objektus reprezentuoja praeiti (4). Beje, vokiečių muzeologas B. Rese [33, 22-23] mano, kad istorija yra vienas iš neišvengiamų eksponavimo turinių visuose muziejuose. Jam pritaria Davidas Andersonas, tvirtindamas, kad visi muziejai, nesvarbu, koks yra jų objektas, yra istorijos muziejai (angl. Museums of History). Jie supažindina lankytojus su istorijos kaip žinių formos prigimtimi ir yra istorinių kolekcijų interpretuotojai [žr. 1, 163].

Istorijos muziejaus sampratos kaita sietina su tarpdalykiškumo tendencijomis ịvariose mokslo srityse ir, žinoma, pokyčiais XX a. istoriografijoje. Joje dẻl patiriamos socialinių mokslų ịtakos vyksta radikalūs struktūros pokyčiai, apsunkinantys griežtų istorijos mokslo rèmų nustatymą (istorinės kultūros / atminties studijose jau tiriama, ne kaip iš tikrųjų buvo, o kaip tam tikrose visuomenèse konstruojami vaizdiniai apie tai, kaip iš tikrųjų buvo (5)). Neišvengiamai ir istorijos muziejų kuratoriai ị pagalbą turi pasitelkti ịvairių žinijos sričių bei krypčių instrumentus: sociologijos, psichologijos, ịvairių etnologijos ir antropologijos krypčių, materialinès ir populiariosios kultūros studijų, industrinès archeologijos ir t. t. sąvokas, koncepcijas, tyrimus [plg. 46; 16, 53].

Lietuvoje muziejų sampratos klausimai menkai svarstomi, tad Lietuvos muzeologè N. Keršyte linkusi laikytis dvejopos istorijos muziejaus sampratos. Jos tyrimuose esama ir muziejų klasifikacijos pagal profilius, ir tvirtinimo, kad etnografijos, kraštotyros, archeologijos muziejus Lietuvoje galima priskirti istorijos muziejams [žr. 20, 13; 18, 28-29] (6).

\section{ISTORIJOS MUZIEJUS KAIP ISTORINĖS KULTŪROS FORMA}

Istorijos muziejus kaip istorinès kultūros forma yra dvilypis. Viena vertus, tai yra viena iš kilnojamojo materialaus paveldo saugyklų (šalia bibliotekų ir archyvų), tačiau ir būdamas paveldo saugykla muziejus yra unikalus. Tai ịrodo žymus vokiečių muzeologas F. Waidacheris. Anot jo, muziejai kaupia atrinktus originalius ir autentiškus tikrovę liudijančius objektus, bibliotekos - informaciją, esančią dokumentuose, o archyvai - raštiškas žinias. Bibliotekoms ir archyvams rūpi ne tiek materiali informacijos šaltinių būtis, kiek pati informacija, esanti spaudiniuose ir dokumentuose, todèl bibliotekos ir archyvai renka mentefaktus, o muziejai - artefaktus ir gamtos objektus [žr. 44, 132, 216]. Kita vertus,

(4) Muziejų klasifikacijos pagal profilius atsisakymas taip pat liudija, jog šis XIX a. pozityvizmo idejju subrandintas skirstymas jau yra istorinis ir nebeatitinka nūdienos realijų [plačiau 13, 84].

(5) Plačiau apie istorinès kultūros sampratą visų pirma žr. [34], taip pat [31].

(6) Tai jai leidžia padaryti svarbią išvadą, jog „Lietuvoje nuo XIX amžiaus vyrauja istorijos muziejų kūrimo tradicija“ $[18,28]$. 
istorijos muziejus tokių komunikacijos formų kaip ekspozicija bei paroda dèka yra vienas iš praeities reprezentavimo pavidalų (šalia istoriografijos, istorinio romano, filmo, laidos ir t. t.). Tenka sutikti su G. Kavanagh, teigiančia, jog jokia kita istorinès kultūros forma negali reprezentuoti praeities taip, kaip tai daroma muziejuje, taigi, ir jo pavaduoti $[16,54]$. Muziejinė komunikacija vyksta rodant ir intepretuojant atrinktus muziejinius eksponatus. Lietuvių muziejininkas Žygintas Būčys (diskutuodamas su istoriko Alfredo Bumblausko Signatarų namų koncepcija, kurioje preferencijos tenka idejos, o ne kolekcijos pateikimui [10, 57-66]) teigia, kad muziejiniai rinkiniai yra muziejiniams naratyvams būtina sąlyga - šie ne tik remiasi muziejiniais daiktais, bet yra iš jų sudaryti. Šiuolaikinès technologijos naudojamos tam, kad padètų išreikšti šiuos naratyvus [4, 62] (7).

Istorijos muziejai turi panašumų su istoriografija: abu yra suformuoti dèl žmogui ir visuomenei būdingo poreikio orientuotis laike. Šis poreikis dažniausiai (žinoma, tai priklauso nuo muziejaus ir istoriografijos pobūdžio) yra racionalizuojamas, t. y. realizuojamas pasitelkus tyrimus. Anot F. Waidacherio [44, 143], moksliniu tyrimu, kuriam būdinga tarpdalykiškumas ir orientacija i pritaikymą, muziejus skiriasi nuo savo pirmtakų ir visų kitų rinkimo, tyrimo, konservavimo, ugdymo ir parodų organizacijų. Tiek istoriografija, tiek muziejai yra veikiami vyraujančių istorinio mąstymo schemų, ideologijų, istorinès kultūros aktualijų. Antai istorinio proceso kompleksiškumo, sudètingų ryšių tarp faktų, reiškinių bei procesų suvokimas XX a. pradžioje ne tik paskatino pokyčius istoriografijoje (pvz., Fernando Braudelio istorinio laiko diferencijavimo samprata [2]), bet ir muziejų ekspozicijos formų permainas. Iki tol vyravusių sisteminių (t. y. tipologinès-chronologinès sekos) ar ansamblio (t. y. aplinkos atkūrimo) pobūdžio ekspozicijų, kuriose naudoti vien muziejiniai objektai, nebepakako, kad būtų parodyti sudètingi istorijos procesai. Atsirado teminis ekspozicijų metodas, kurio pagrindas buvo tema, idejja, problema, siužetas, o jo igyvendinimas vyko pasitelkus įvairią ekspozicinę medžiagą [33, 80-81].

Esama ir esminių skirtumų tarp muziejinès ekspozicijos ir istoriografijos. Muziejinès ekspozicijos suvokimas yra daugiasluoksnis procesas, kuriame dalyvauja visos juslès, bet vyrauja rega [žr. 44, 159]. Turime reikalą su vizualine komunikacija, todèl ekspoziciją galime ịvardyti vizualinés medijos terminu. Sąvoka medija čia suvokiama ne masinès komunikacijos priemonių (angl. mass media), bet komunikacijos tarpininko (mediumo), kuriančio naujas komunikacijos erdves, prasme (8). Komunikacijos tyrimai rodo, kad vizualinè medija, skirtingai nei rašytinè (pvz., istoriografija), yra suvokiama dažniau asociatyviai, emocionaliai, o ne diskursyviai. Esant diskursyviam informacijos apdorojimui, reikšmingos ne tik informacijos gavejo asmeninès savybès, bet ir siūlomos informacijos loginè struktūra. Asociatyvaus apdorojimo metu lemiamas yra ịgyjamas ịspūdis, kuris pirmiausia yra emocionalus ir, aišku, privatus (reaguojama: kaip gražu ar kaip blogai, kaip malonu ar bjauru). Pastaruoju atveju recipientui yra svarbu, ne ką sako / rodo, bet kas ir kaip ką nors sako (ar galima juo tikèti, ar jis simpatiškas, koks mano santykis su juo) [33, 104; 14].

Kitas esminis skirtumas tarp muziejinès ekspozicijos ir istoriografijos kyla dèl tiriamų ir interpretuojamų šaltinių specifikos. Ekspozicija nèra ar neturètų būti mokslo teiginių

(7) Beje, minèta A. Bumblausko Signatarų namų koncepcija sulaukè ir filosofo Arūno Sverdiolo [39, 188-195] kritikos ne tik dèl idèjos reprezentavimui teikiamos pirmenybès, bet ir pakaitalų (kitaip - muliažų, kopijų) toleravimo. Tai, kad filosofo kritika nèra pelnyta, rodytų šio straipsnio poskyryje „'Idealaus' šiuolaikinio istorijos muziejaus paieškos" pateikti Tomislavo Šola tradicinio ir modernaus muziejaus apibrěžimai.

(8) Plačiau apie ịvairias sąvokos „medija“ sampratas žr. [28]. 
iliustracija pasitelkus muziejinius eksponatus bei kitą medžiagą (9). G. Kavanagh [16, 6364] teigimu, istorikų klausimai, suponuoti siaurų temų, sufokusuoti ị pagrindinę idèją, ieškomi rašytiniuose dokumentuose, nèra tinkami istorijos muziejų kuratoriams, dirbantiems su materialiuoju kultūros paveldu (10). Jų atsakymai apie praeitị slypi dvejopame muziejinio objekto „skaityme“. Pirmasis (kitaip - klasikinis) skaitymas tai - vidinė objekto analizè. Tiriamos jo fizinès charakteristikos: medžiaga, konstrukcija, struktūra, forma, stilius, ornamentika ir t. t. [žr. 16, 112; taip pat žr. 3, 48]. Kitas analizès klodas - objekto socialinès reikšmės ir konteksto (socialinių ryšių) tyrimas [žr. 16, 112]. Siekiant atkurti ryšius tarp daiktų ir reiškinių svarbų vaidmenị Vakarų muziejų kultūroje vaidina socialinès-kultūrinès antropologijos prieiga, kuri, anot antropologo Romo Vaštoko, kultūrą laiko „ne daiktų ir veiksmų kolekcija, o dinamišku, atsinaujinančiu, nesibaigiančiu veiklos tinklu" [5, 53-54]. Specifinis darbas su istorijos šaltiniais lemia tai, kad istorijos muziejai turètų užsiimti labiau sinchroninėmis, o ne diachroninèmis praeities studijomis, turi daugiau galimybių pateikti ne vienalinijinị, o daugiadimensinị praeities vaizdinị, pabrèžti ne įvykį ar jų seką, o epizodą, struktūrą, ryšius. Taigi, reprezentuojant praeitį muziejuose pagrindiné yra buvimo (angl. being), o ne tapsmo (angl. becoming) kategorija [16, 62-65]. Šie daugiau normatyvinio pobūdžio teiginiai nurodo tam tikras „idealaus“ šiuolaikinio naratyvo istorijos muziejuje gaires.

\section{3. „IDEALAUS“ ŠIUOLAIKINIO NARATYVO ISTORIJOS MUZIEJUOSE PAIEŠKOS}

Istorijos muziejui galioja visiems muziejams taikomi šiuolaikiškumo (kitaip - naujumo, modernumo, atitikimo šiandienos poreikius) reikalavimai. Griežtą tradicinių ir naujų muziejų distinkciją nubrèžè tuometinès Jugoslavijos muzeologas Tomislavas Šola 1986 m. Meksikoje UNESCO surengtame seminare [žr. 49, 29]. Tradicinis muziejus pateikiamas kaip konformistine ịstaiga, kuriai būdinga racionali, formali bei autoritetinè prieigos, objektyvumo, moksliškumo vertybe், orientacija ị baigtinị rezultatą, eksponatų demonstravimas, dèmesys praeičiai. Naujasis muziejus tai - nekonformistinè įstaiga, kuri siekia nuolat atsinaujinti, neformalios ir komunikatyvios prieigos. Tai reiškia, kad joje atsižvelgiama i emocionalumą, atspindimas pasaulio platumas, pabrèžiamas kūrybiškumas, suprantamumas visiems, pažinimo procesas, įvaizdijant koncepcijas nevengiama eksponuoti kopijų, dèmesys sutelkiamas ne vien ị praeitị, bet ir dabartị. Šios apibrèžtys siejasi su 1972 m. Čilejje vykusioje konferencijoje „Naujoji muzeologija“ pateiktomis formuluotėmis. Modernaus muziejaus tikslu čia laikomas ne medžiaginio palikimo saugojimas, o tapatybės formavimas, kasdienybės įveika, visuomenès plètotè. Tai turi būti igyvendinama pabrèžiant sudètingą tikrovę, tarpdalykiškumą, orientuojantis ị temą, praeitị siejant su dabartimi, bendradarbiaujant su vietos ar regiono organizacijomis [44, 97-98]. Ž. Būčys, svarstydamas muziejaus modernumo klausimus, pabrěžia kiek kitus dalykus. Anot jo, muziejaus šiuolaikiškumas - „tai visų pirma diskusija tarp lankytojo ir eksponato, bendravimas ir pašnekesys, vedantys savęs bei kitų pažinimo link“ $[4,62]$. Šios mintys artimos G. Kavanagh muziejaus kaip fantazijos erdvès (angl. dream space) sampratai, kurioje pabrěžiamas ligi tol ignoruotas asmeninis, subjektyvus, o ne mokslinis, objektyvus, ekspozicijos „skaitymas“ $[15,161]$. Tačiau tam, kad

(9) Kiek kitaip kalba lenkų muzeologas Wojcechas Gluzińskis. Jis teigia, kad muziejinès ekspozicijos fizinè tikrovè turi iliustruoti dalykinès mokslo kalbos teiginius, kurie liečia ne muziejinę tikrovę, bet gamtinès ar socialinès tikrovès reiškinius [11, 434-435].

(10) Šis teiginys netinka istorikams, kurie imasi socialinio gyvenimo aspektų tyrimo, nę̣sivaizduojamo be materialinès kultūros studijų $[45,77]$. 
istorijos muziejus taptų dialogo erdve, visgi būtinos tam tikros prielaidos. Istorijos muziejams keliamus reikalavimus, išsakomus daugelyje veikalų ir straipsnių, mūsų nuomone, iškalbingiausiai apibendrina austrų muziejininko Wolfgango Koso „muziejų kuratorių mantra“: „Daugiau nepasakokite istorijos iš valdžios ir daugumos pozicijų. Suteikite balsą tiems, kurie iki šiol nereprezentuojami muziejuje. Gerbkite įvairovę. Pasakokite apie kasdienybès gyvenimą, o ne apie išskirtinius ịvykius. Aiškinkite kontekstus. Svarstykite neseną istoriją, netgi tai, kas vyksta šiandien. Būkite pakyla kritiškam balsui“ $[22,128]$. Atkreiptinas dèmesys, kad W. Koso pateikti imperatyvai (skirtingai nei anksčiau pateiktuose modernaus muziejaus apibrèžimuose išsakyti reikalavimai) daugiausia pabrèžia istorijos turinio aspektus, kurie yra taikomi daugeliui šiuolaikinès istorinès kultūros formų: istoriografijai, istoriniui filmui, laidai ir t. t.

Taigi, pirmoji prielaida - oficialiosios, vyraujančios istorijos, visuotinai paplitusių tiesų (mitų) apie praeiti atsisakymas. Tiesa, čia matoma alternatyva. W. Kosas teigia, kad muziejuose būtina eksplikuoti mitus, nes būdami visuomenès vertybių ir standartų veidrodžiu jie leidžia pažinti pačią visuomenę bei sukelia diskusijas [22, 133].

Reikalavimas atsisakyti oficialiosios, vyraujančios istorijos, visuotinai paplitusių tiesų apie praeitị siejasi su būtinybe reprezentuoti alternatyvias istorijas: lokalias, kasdienes, marginalias (pvz., imigrantų), nevyraujančias (pvz., etninių mažumų, moterų), artimas dabarčiai (11). Temų, aspektų, atminčių ívairovẻ - ugdymo procesų muziejuje prielaida, nes lankytojai mokosi tuomet, kai tai, ką mato, susieja su tuo, ką žino [žr. 15, 153, 156]. Istorijos televizijoje tyrèjo Dieterio Schmidto-Sinnso $[38,11]$ nuomone, sèkmingiausi istorinès ar kultūrinès informacijos šaltiniai yra tie, kurie paliečia asmenines žiūrovo gyvenimo istorijas, kurie suponuoja naujų turinių integravimą i autobiografinị pasakojimą. Anot Johno Kinardo [47, 41], muziejus plačiajai publikai dažniausiai siūlo informaciją, nesusijusią su jos paveldu, šiandienos poreikiais bei ateities lūkesčiais. Apie buvimą anapus muziejinès reprezentacijos ribų iškalbingai liudija šie Zoros Martin-Felton žodžiai: „Aš dairausi aplinkui, tačiau nematau nieko, kas būtų panašus ị mane. Aš klausausi, tačiau negirdžiu, kad kas nors tartų mano vardą" [cituota iš: 47, 43]. Temų, aspektų, atminčių ịvairovè istorijos muziejuose ne tik suponuoja savos patirties atpažinimą, smalsumo sužadinimą, bet ir lemia kitokio istorijos vaizdinio susiformavimą. Praeitis iškyla ne kaip statiška, nuosekli, harmoninga, geresnè už dabartị, bet patirianti ịvairias ịtakas, kintanti, kupina konfliktų, ittampų, prieštaravimų, chaotiška, atsitiktinè. Būtent pastarasis istorijos vaizdinys, išgaunamas naudojant ne tiek naratyvines ar deskriptyvines, o labiau analitines eksponavimo formas bei drąsius eksponavimo stilius, padeda ugdyti kritini mąstymą, atverti erdves savoms interpretacijoms, dialogui su praeitimi.

Savaime suprantama, istorijos muziejuose imantis išvardytų temų bei uždavinių būtina atsisakyti izoliuoto nuo konteksto muziejinių objektų eksponavimo. Dėmesys turètų būti sutelkiamas ị socialinių ryšių atskleidimą. Kaip žinia, muzealijos yra praeities fragmentai, kurie patys savaime nesupažindina mūsų su istoriniu kontekstu, nes izoliuoti nuo savo funkcinių ryšių jie neturi santykio su savo pirmine, praktine aplinka. Kaip pažymi Diethardas Herlesas [13, 65] ir Sigrid Godau [12, 200], muzealijos neturi jokio istorinio turinio, yra istoriškai „tuščios“, abejingos laikui ir pažinios tik estetiškai. Tam, kad muziejiniai praeities fragmentai imtų byloti apie praeitị, būtinas rekontekstualizavimo (buvusių objekto aplinkybių atkūrimo) veiksmas. Kaip tai igyvendinama? D. Herleso [13, 68] manymu, kadangi „sumuziejintas“ objektas muziejuje prezentuoja tik save, o reikšmès turi būti

(11) Muziejuose galimų temų, aspektų ịvairovę geriausiai atspindi G. Kavanagh sudarytas veikalas [27]. 
atidengtos ir atrastos, objekto istorinė reikšmė tampa akivaizdi tik esant ryšiui su kažkuo kitu (tarp jų ir didaktinėmis priemonèmis).

Ar tinka minèti, daugiausia užsienio muzeologų, teiginiai istorijos muziejų Lietuvoje analizei? Manytume, kad taip. Nūdienė Lietuvos istorinė kultūra kaip niekad anksčiau yra atvira iš svetur kilusioms sampratoms. Daugelis minètų temų dèl ịvairovės, lokalumo, kritinio mąstymo ir kitų idejų jau ne vienerius metus yra sẻkmingai taikomos istorijos tyrimuose. Tai, ar idejų ir vertybių pliuralizmo laikais jos galioja ir mūsų muziejams, pabandysime išsiaiškinti paanalizavę Vilniaus muziejus.

\section{VILNIUS KAIP VYRAUJANČIŲ IR ALTERNATYVIŲ MUZIEJINIŲ NARATYVŲ POLILOGO ERDVE்}

Jei, anot N. Keršytès, Lietuva yra istorijos muziejų šalis, tai Vilnius - istorijos muziejų miestas. Šios muzeologès teigimu, sostinès muziejai sudaro $1 / 3$ visų muziejų Lietuvoje $[20,13]$. Tiesa, suskaičiuoti, kiek Lietuvos sostinejje tiksliai yra istorijos muziejų (suprantamų plačiąja prasme), tiek N. Keršytei [20, 12], tiek ir šio straipsnio autorei buvo sudettinga dèl pateikiamos skirtingos statistinès informacijos. Sukurti skirtingais istoriniais tarpsniais ir / ar paveldèję privačių kolekcininkų, draugijų bei neišlikusių muziejų rinkinius, Vilniaus miesto muziejų rinkiniai ir ekspozicijų erdvès atspindi ịvairių laikmečių visuomenių mąstymo schemas, vertybių sistemas, skirtingas kultūras. Šio miesto muziejų kultūra gali būti traktuojama kaip naratyvų raizginys, kuriame įvairūs klodai koegzistuoja ar vienas klodas užkloja bei keičia kitą. Kokie tai naratyvai? Ar tai - vyraujantys pasakojimai, kurie suprantami ne tik kaip elitinèje ir oficialiojoje aplinkoje įsitvirtinę požiūriai (pagrindinès mąstymo schemos), bet ir jų pateikimo kanonizuoti būdai, ar egzistuoja alternatyvūs turiniai, naujos muziejinės reprezentacijos formos? Ir koks pirmųjų santykis su antraisiais?

\section{1. VYRAUJANTYS PASAKOJIMAI VISUOMENĖS ISTORINĖS SĄMONĖS KONTEKSTUOSE}

Vilniuje kaip Lietuvos sostineje yra net trijų nacionalinių (t. y. svarbiausių valstybèje) muziejų - Lietuvos nacionalinio muziejaus, Lietuvos dailès muziejaus ir Lietuvos Didžiosios Kunigaikštystės Valdovų rūmų - filialai. Juose tiriami, restauruojami, konservuojami ir eksponuojami svarbiausių valstybės istorijos, meno, technikos, gamtos ir kitokių vertybių rinkiniai, kurių dalis paveldèta net iš XIX a. vidurio - XX a. pradžios muziejų ir draugijų kolekcijų. Nacionalinio muziejaus statusas įpareigoja tautinio ar pilietinio identiteto formavimo ir įtvirtinimo misijai, kuri tapo įmanoma tik atkūrus valstybingumą. Ši savo ruožtu sąlygoja savitus istorijos ir kultūros reprezentavimo kanonus: vengti prieštaravimų, marginalijų, poetiškumo, ironijos, pateikti monoperspektyvų, „uždarą“, romantizuotą istorijos vaizdą (12). Tai leidžia teigti, jog nacionaliniams muziejams, kaip svarbiausių valstybejje rinkinių saugotojams, interpretuotojams ir perteikejjams, artimesni tradiciniams, o ne moderniems muziejams priskirtini uždaviniai, tikslai, prioritetai ir t. t., eksplikuoti ankstesniame poskyryje. Šiuose muziejuose vyraujantys naratyvai (juos įvardijame kaip tautinius) pabrěžia lietuvių tautos ir valstybingumo istoriją. Juos išvystame Lietuvos nacionalinio muziejaus Naujojo ir Senojo arsenalų, Gedimino pilies bokšto, Signatarų namų erdvėse, Lietuvos dailès muziejaus Vilniaus paveikslų galerijos iškiliausių XVI-XXI a. Lietuvos dailès kūrinių ekspozicijoje, visuomenès susidomejjimo sulaukusiose tarptautinèse ir vietinèse istorinèse parodose Taikomosios dailès muziejuje bei Radvilų rūmuose, Valdovų rūmų parodose, laikinai besiglaudžiančiose kitų Lietuvos muziejų salèse. Čia daugiausia

(12) Apie valstybės identiteto reprezentavimo muziejuose tradicijas ir jų kritiką plačiau žr. [48, 52-53]. 
susitelkiama $\mathfrak{i}$ tam tikrus tarpsnius: tautos ir valstybės ištakas (Senasis arsenalas), valstybingumo susiformavimo, klestejjimo ir nuosmukio periodus (Naujasis arsenalas, Valdovų rūmai, Vilniaus paveikslų galerija, Radvilų rūmai, Taikomosios dailès muziejus, Gedimino pilies bokšto ekspozicinès erdvès), valstybingumo palaikymo bei susigrąžinimo kultūrinių ir politinių pastangų etapus (Naujasis arsenalas, Gedimino pilies bokštas, Signatarų namai). Nemažai dėmesio skiriama ir ịvairių epochų Lietuvos kultūrai.

Vyraujantys naratyvai paprastai ịvardijami kaip etnocentriniai. Anot vokiečių istorijos teoretiko Jörno Rüseno, etnocentrizmas - viena iš daugelio pasaulio interpretacijos ir savivokos praktikų, kurioje iškeliamas socialinio darinio vientisumas, o priklausomybe šiam socialiniam dariniui susiejama su tariamai objektyviais, natūraliais kriterijais [35, 264]. Teigti, kad išvardytų muziejų ekspozicijose ir parodose diegiama etnocentriné Lietuvos kultūros ir istorijos samprata (kurios svarbiausi bruožai yra lietuvių tautos suvokimas etniniu požiūriu, Lietuvos valstybingumo, kultūros kaip etninių lietuvių veiklos rezultato traktavimas, lietuvių kalbos ir lietuviškos kilmės akcentavimas), būtų neteisinga. Visų pirma ekspozicijose pabrèžiamas LDK daugiakultūriškumas, ir tai rodo policentrinę Lietuvos kultūros sampratą. Antra, Lietuvos dailès muziejaus ir Valdovų rūmų dėmesys dvarų kultūrai ir dailès bei architektūros istorijai atsieja lietuviškumo apibrèžtị nuo lietuvių kalbos ir lietuviškos kilmès dèmenų. Šie muziejai, dèmesị sutelkdami į nekalbinėmis priemonėmis sukurtus ženklus ir simbolius, nesiima jų dirbtinai priskirti kalbiniu požiūriu suskaidytoms tradicijoms (t. y. lietuviškoms ir nelietuviškoms), o visą eksponuojamą kultūros paveldą traktuoja kaip Lietuvos kultūros savastị. Visa tai ir liudija istorinę-evoliucionistinę lietuviškumo sampratą, kuri pripažįsta tautos, tautiškumo turinių kaitą istorijos eigoje. Be to, Lietuvos dailès muziejaus ir Valdovų rūmų senosios Lietuvos istorijai skirtose ekspozicijose ir parodose, dažniausiai naudojant kolekcinị eksponavimo principą, labiausiai pabrěžiama materiali senosios Lietuvos istorijos šaltinių būtis, kuri savaime yra daugiareikšmè. Tai rodytų, kad sociologiniuose Lietuvos visuomenès tyrimuose [žr. 41-43] pastebimos istorinès sąmonès slinktys nuo lituanocentrinių, romantinio etninio nacionalizmo paveiktų praeities interpretacijų link Lietuvos etnines grupes integruojančių, įtampas mažinančių pasakojimų, perteikiančių pilietinio lietuviškumo, tolerancijos, europietiškumo vertybes, matomos ir vyraujančiuose muziejiniuose pasakojimuose. Istorinèje kultūroje tam tikra praeities reprezentacijos forma traktuotina ir kaip istorinės sąmonès veiksnys, ir kaip jos išraiška, todèl minèti muziejiniai naratyvai tuo pat metu laikytini ir kaip vieni iš visuomenès istorinę sąmonę keitusių šaltinių (šalia istoriografijos, kino, TV, daugialypès terpès kūrinių ir t. t.), ir kaip besikeičiančių sampratų pasekmè.

Visgi tai, kad Lietuvos kultūros istorijos ir paveldo skaidymas etnolingvistiniu požiūriu yra i̇manomas ir nepasenęs, rodo respublikinį statusą turinčio Lietuvos teatro, muzikos ir kino muziejaus nuolatinè ekspozicija „Iš teatro, muzikos ir kino muziejaus rinkinių. XIX a. - XX a. pirmoji pusé“ Vilniuje. Atrodytų, kad etnocentrinės sampratos čia laikomasi reprezentuojant Lietuvos teatro istoriją. Etnolingvistinis kultūros traktavimas lèmè griežtą atskirtị tarp lietuviškai ir nelietuviškai kalbejjusių Lietuvos teatrų ir Lietuvos teatro istoriją pavẻlino keliais šimtmečiais - jo ankstyviausios ištakos matomos tik XIX amžiuje. Manyti, kad ekspozicijos kūrèjai nèra nuoseklūs etnocentrinès sampratos šalininkai ir kad minètas apsiribojimas greičiausiai yra nulemtas kolekcinio eksponavimo principo, skatina pats nuolatinès ekspozicijos pavadinimas (šis liudija, jog susitelkiama ì medžiaginius objektu turinius, sinchroninius epizodus bei ryšius, o ne į nuoseklią Lietuvos teatro, muzikos ir kino istoriją) bei XVI amžiumi datuojami eksponatai muzikos istorijai skirtose salèse. 
Tačiau etniniu požiūriu įmanoma atskirti ne tik kultūros istoriją, bet ir tos valstybès piliečių kančias, patirtas XX a. politinių įvykių verpetuose. Tą liudija dauguma Genocido aukų muziejaus ekspozicijų ir Valstybinio Vilniaus Gaono žydų muziejaus holokaustui skirta ekspozicija. Šio atskyrimo priežastys slypi ne tiek muziejų rinkinių bei jų eksponavimo specifikoje, kiek visuomenès istorinèje kultūroje. Istorikų Alvydo Nikžentaičio [30, 447] ir Vasilijaus Safronovo [36, 351-352, 360-364] nuomone, holokausto Lietuvoje temos nutylèjimas sovietmečiu bei lietuvių tautos kančių atminties ịsitvirtinimas Atgimimo ir vèlesniais metais sąlygojo žydų žudynių (kuriose, deja, dalis etninių lietuvių atliko ne tik gelbètojų, bet ir žudikų pagalbininkų vaidmenị) fakto ignoravimą ar nuvertinimą. Pastarasis pasireiškẻ ịtvirtinant dviejų genocidų - lietuvių ir žydų - sampratą, ir tą rodo ne tik atmintinų dienų sąrašas, bet ir skirtingų muziejinių naratyvų egzistavimas. Genocido aukų muziejuje $2011 \mathrm{~m}$. pabaigoje atidaryta nacių okupacijai ir holokausto aukoms skirta ekspozicinė erdvė laikytina pirmuoju bandymu sujungti šiuos pasakojimus.

\section{2. ALTERNATYVIŲ PASAKOJIMŲ LINK}

Vilniaus muziejų kultūroje šalia vyraujančių pasakojimų galima atrasti ir alternatyvių naratyvų. Juose beveik nèra vyraujančių praeities interpretacijų suprobleminimo, jų pagrịstumo atmetimo, demitifikacijos, kas leistų juos laikyti kontristorijomis. Tai veikiau vyraujančių pasakojimų papildymas įvairiais praeities aspektais, kitaip - „mažaisiais pasakojimais“, neturinčiais pretenzijų nusakyti galutinị tautos ir valstybės tikslą, politiškai orientuoti ir mobilizuoti. Muziejinemis nuorodomis $\mathfrak{i}$ tam tikras alternatyvias socialines tikroves veikiau siekiama, kad šios tikrovès būtų dar kartą atpažintos, prisimintos, susietos su pačių lankytojų išgyventa patirtimi.

Vyraujančio ir lokalaus naratyvų dermės pavyzdys Vilniuje - šio miesto savivaldybei pavaldus Marijos ir Jurgio Šlapelių namas-muziejus. Tam tikrais bruožais jis yra artimas Lietuvos nacionalinio muziejaus padaliniui - Signatarų namams. Abu muziejai įkurdinti toje pačioje Pilies gatvejje XVII a. ir senesnius amžius menančiuose istoriniuose pastatuose - valstybei ir tautai svarbių ịvykių bei procesų liudytojuose. Abiejų ekspozicijose dèmesys sutelkiamas ị XIX a. antrosios pusès - XX a. pirmosios pusès Lietuvos istorijos ịvykius, abiejuose esama memorialinio pobūdžio ekspozicijų. Tačiau esminis skirtumas tas, kad Marijos ir Jurgio Šlapelių name-muziejuje Lietuvos istorija glaudžiai susiejama su šiame pastate gyvenusių vilniečių Šlapelių ir jų bendraminčių kasdiena, kultūriniais rūpesčiais bei Vilniaus praeitimi XIX a. pabaigoje - XX a. pirmojoje pusejje. Lokalumo dèmeniui išreikšti itin paranki memorialinio muziejaus forma bei to meto namų ir darbo kasdienybę menančios ekspozicijos (gyvenamieji kambariai, lietuvių knygynas) nedidelèse jaukiose erdvèse.

Lokalių kasdienybės ir nesenos istorijos naratyvų galima atrasti ir Energetikos ir technikos muziejuje Vilniuje. Šie muziejiniai pasakojimai - alternatyva siaurai suprantamam technikos istorijos pateikimui, kuriam būdinga objektų tipų istorija, technologinio progreso idejja, industrinio paveldo pastatų ir objektų mistifikacija (13). Šios tradicinès prieigos daugiau ar mažiau esama ne tik minimame muziejuje, bet ir kituose technikos muziejuose Vilniuje: naujajame Geležinkelių muziejuje, Lietuvos radijo ir televizijos muziejuje, Vytauto Didžiojo karo muziejaus padalinyje Vilniuje - Karo technikos ir transporto muziejuje ir t. t. Alternatyvūs naratyvai matomi Energetikos ir technikos muziejaus ekspozicijoje „Pagaminta Vilniuje“. Pastarojoje teminiu principu sukurtoje ekspozicijoje demesys sutelkiamas ne tik ị technikos objektus, gaminius, bet ir juos kūrusius žmones, Vilniaus

(13) Plačiau apie technikos istorijos pateikimo muziejuose būdus ir jų kritiką žr. [9; 13, 90-94]. 
industrializacijos poveikị miestovaizdžiui bei kasdieniam gyvenimui. Tai rodo, kad pamažu atsisakoma technologijos matymo anapus visuomenès, siekiama technikos istorijos sąsajų su socialine, kultūrine ir kitomis praeities dimensijomis.

Po 1990-ųjų apleista ekonomikos istorijos sritis pateikiama Lietuvos banko Pinigų muziejuje Vilniuje. Šio muziejaus alternatyvumas slypi ne tik pasirenkant istorinėje kultūroje nevyraujančią temą - pinigų ir bankininkystès pasaulyje bei Lietuvoje praeitị ir dabartị, bet ir ją reprezentuojant. Pinigų ir bankininkystès raida čia skaidoma ị lengvai suprantamas temas, artimas mokyklinių vadovẻlių paragrafų pavadinimams: „Kai pinigai dar buvo prekès“, „Ypatingų aplinkybių pinigai“, „Pinigų klastojimas“, „Bankininkystès pradžia: kada, kur ir kaip?" ir t. t., kurios atskleidžiamos ne vien tipologiniu-sisteminiu principu demonstruojamais muziejiniais objektais. Šias muziejines vertybes rekontekstualizuoja bei paaiškina tekstai su iliustracijomis, filmai, lavinamieji žaidimai ir kitokių edukacinių pramogų pasiūla kompiuteriniuose terminaluose, „dalyvavimo“ efekto potyriai (galimybė pačiam lankytojui nusikalti suvenyrinę plokštelę, pasisverti ant specialių svarstyklių ir t. t.).

Drąsiai galima teigti, kad alternatyvių temų ir sprendimų paieškų lyderis yra Nacionalinè dailès galerija, Lietuvos dailès muziejaus padalinys. Dailès istorijos ekspozicijoms ir parodoms (tarp jų ir Vilniaus muziejuose) paprastai yra būdingas izoliuotas nuo konteksto meno kūrinių eksponavimas. Šių objektų izoliacija pabrèžia jų vienkartinumą, autonominę egzistenciją, juos kaip vertingus artefaktus (o ne istorines liekanas), iškelia meną virš kitų kultūrinių reiškinių. Antai $\mathrm{D}$. Herlesas yra atkreipęs dèmesį, kad iš muziejinių rinkinių meno ekspozicijai yra atrenkami ne tipiški tam tikram laikmečiui, o ypatingi kūriniai. Tai rodo, kad atrankos kriterijus meno muziejuose yra objekto kokybinè (estetinė) verte, kuri vargu ar paaiškina ryšius tarp meninès produkcijos ir nemeninès realybès [plačiau 13, 72, 75-80]. Tai, kad dailès muziejuje kultūrinị ir istorinį rekontekstualizavimą įmanoma atkurti savitomis priemonèmis, rodo Nacionalinès dailès galerijos atidarymo proga pristatyta tarptautinè paroda „Spalvų ir garsų dialogai. M. K. Čiurlionio ir amžininkų kūryba“. Beje, M. K. Čiurlionio kūrybos kontekstas čia - ne politinis ar socialinis, o estetinis ir vertybinis. Jis kurtas pateikiant jo amžininkų dailininkų ir kompozitorių Vakarų ir Vidurio Europoje kūrybą. Tam taikytas ne dailès muziejuose dažnas chronologinis ir / ar autorinis, o teminis („Gamtos garsai“, „Visatos tyla“, „Miestų gausmas“ ir t. t.) kūrinių eksponavimo principas. Šis principas buvo pasitelktas Nacionalinès dailès galerijoje reprezentuojant ir tas, kurios retai būna muziejinès reprezentacijos dèmesio centre, t. y. moteris. Tiesa, teigti, jog moters reprezentacijų Vilniaus muziejų ekspozicijų ir parodų salèse mes neatrasime, negalima. Vilniuje yra dainininkei Beatričei Grincevičiūtei skirtas memorialinis butas-muziejus, minètoje Lietuvos teatro, muzikos ir kino muziejaus ekspozicijoje „Iš teatro, muzikos ir kino muziejaus rinkinių. XIX a. - XX a. pirma pusé" eksponuojama daug muziejinių objektų, perteikiančių moters veiklos viešumoje temą, Valstybinio Vilniaus Gaono žydų muziejaus holokausto ekspozicijoje matoma aktyviai politiniuose įvykiuose veikiančių ir nuo jų kenčiančių žydų moterų ivvaizdžių, Nacionalinio muziejaus Naujajame ir Senajame arsenaluose koncentruojamasi ties lietuvių moters kasdiena ir t. t. Tačiau peržvelgus šiuose muziejuose reprezentuojamus moters ịvaizdžius tenka sutikti su britų muzeologe Elizabeth Carnegie, teigiančia, jog esama tendencijos matyti tik pozityvius moters gyvenimo aspektus, vengiama atskleisti prieštaravimus, problemas [6, 59-60]. Šiame kontekste išimtimi laikytina Nacionalinès dailès galerijos paroda „Moters laikas. Skulptūra ir kinas“. Siekiant atskleisti moterị kaip socialinę-kultūrinę kategoriją, čia imtasi eksplikuoti pati moters mitą, tiksliau, jo raiškos būdus sovietinès Lietuvos skulptūroje ir dokumentikoje. Atrasti penki oficialiojoje aplinkoje tiražuoti moters 
įvaizdžiai: didvyrè bei herojè, darbo žmogus, motina, puošmena ir ideologinès, estetinès bei kitokios dekonstrukcijos objektas. Šie moters mitai buvo atskleisti grupuojant ekspozicijos medžiagą penkiuose teminiuose „salynuose“: „Didvyrès ir herojès“, „Socialiniai kūnai“, „Privačios erdvès“, „Moteris-puošmena“, „Dekonstruota“. Tai, kad parodai buvo pasirinkti ilgus metus muziejų saugyklose, menininkų dirbtuvėse, privačiose kolekcijose laikyti skulptūros darbai $[25,76]$, rodo, jog eksponato atrankos kriterijumi buvo ne kūrinio estetinè vertè (būdingiausia meno muziejams), o jo tipiškumas tam tikru laikmečiu. Meno kaip tam tikro laikotarpio vertybių, mąstymo schemų išraiškos traktavimas, jo intencionalumo pabrèžimas nèra tik paminėtų Nacionalinės dailès galerijos parodų išskirtinis bruožas. Tokios parodos kaip „Modernizacija XX a. 7-8 dešimtmečių: Baltijos šalių menas, dizainas ir architektūra“ ir „Mūsų metamorfiškoji ateitis. Dizainas, techninė estetika ir eksperimentinè architektūra Sovietų Sąjungoje 1960-1980 m.“ rodo, kad „migracija“ iš meno (kur svarbiausia formalūs kriterijai) ị kultūros sritị (kur laikomasi rekontekstinių taisyklių (14)) tampa Nacionalinès dailès galerijos muziejinių naratyvų apie praeitị tradicija.

\section{IŠVADOS}

1. Užsienio ir Lietuvos muzeologų teiginiai leidžia tvirtinti, jog istorijos muziejais gali būti laikomi visi muziejai, kurie, pasitelkdami muziejinius pasakojimus, reprezentuoja tam tikrą praeitį: politinę, socialinę, kultūrinę, technologinę, civilizacinę ir t. t. Ši istorijos muziejaus samprata apima ịvairiems profiliams priskirtinus muziejus (istorijos, kultūros istorijos, etnografijos, archeologijos, meno, technikos ir mokslo ir t. t.) ir traktuoja juos kaip istorinès kultūros formas, kurios, pateikdamos tam tikras istorines ir kultūrines orientacijas, formuoja bei reprezentuoja visuomenès istorinę sąmonę.

2. Istorijos muziejuose praeitis reprezentuojama pasitelkus muziejinius pasakojimus $-\mathfrak{i}$ tam tikras prasmingas visumas susietus ekspozicijos elementus. Svarbiausia prielaida šiems pasakojimams rastis - muziejuose renkami, saugomi, tiriami muziejinių objektų rinkiniai. Tokių pagrindinių muziejaus veiklų kaip kultūros paveldo saugyklos ir šio paveldo interpretuotojo neatsiejamumas nulemia šio instituto išskirtinumą kitų istorinès kultūros instancijų atžvilgiu.

3. Muziejaus kaip istorinès kultūros instancijos išskirtinumas sąlygoja tai, jog jam keliami ne tik „universalūs“ (taikytini daugeliui istorinès kultūros formų), bet ir specifiniai modernumo reikalavimai. Universaliais laikytini šie imperatyvai: praeities sąsajų su dabartimi atskleidimas, oficialiosios, vyraujančios istorijos, paplitusių tiesų (mitų) apie praeitị atsisakymas, temų, aspektų, atminčių ịvairovès reprezentavimas, kritiškumo demonstravimas. Specifiniais muziejui laikytini šie reikalavimai: socialinè misija, dėmesys temoms, o ne muziejiniams objektams, orientacija ne ị siauros specializacijos nulemtą perspektyvą, o pasaulio platumą, emocionalumo, kūrybiškumo, suprantamumo visiems bei pažinimo proceso pabrěžimas, atsisakymas iliustruoti istoriografijos teiginius, dėmesys socialiniams ryšiams, struktūroms, epizodams pasitelkus muziejinių objektų rekontekstualizacijos priemones.

4. Vilniaus muziejų analizė rodo, kad šio miesto muziejinių naratyvų įvairovẻje ženklų svorị turi vyraujantys pasakojimai. Jais laikytini oficialiojoje ir elitinejje Lietuvos aplinkoje issitvirtinę tautiniai naratyvai, kuriuose pabrèžiama lietuvių tautos ir valstybingumo istorija, teikiami kolektyviniai Lietuvos istorijos ir kultūros vaizdiniai, telkiantys visuomenę veikti išvien. Jų vyravimas Vilniaus muziejinèje kultūroje nulemtas tik kiek daugiau nei du dešimtmečius siekiančios atkurto valstybingumo istorijos (t. y. visuomenès intereso tautos ir valstybès

(14) Apie muziejinių objektų „migraciją“ tarp meno ir kultūros sričių plačiau žr. [7, 324-333]. 
istorijai) bei nacionalinių muziejų filialų koncentracija Vilniuje. Nacionaliniuose muziejuose lietuvių tautos ir valstybingumo istorija pristatoma muziejinį objektą pabrèžiančiais eksponavimo būdais pirmenybę teikiant objektyvumui, autoritetui, dèmesiui praeičiai. Šios savybès muzeologinèje literatūroje priskiriamos tradicinių muziejų grupei. Nacionaliniuose ir kito statuso Vilniaus muziejuose vyraujančiuose pasakojimuose atrandame tiek etnocentrinių (lietuvių tautą suvokiančių etniniu požiūriu), tiek ir policentrinių interpretacijų (Lietuvos kultūrą ir istoriją traktuojančių kaip visų jos gyventojų veiklos rezultatą), istorinį tautos turinị pabrèžiančiu aiškinimų. Šios interpretacijos yra nulemtos ne tik istorijos muziejaus kaip visuomenès istorinès sąmonès veiksnio ir reprezentanto vaidmens, bet ir muziejinių objektų materialios būties daugiareikšmiškumo, pasiduodančio įvairioms traktuotėms.

5. Šalia vyraujančių muziejinių pasakojimų Vilniaus muziejuose koegzistuoja alternatyvūs, arba „mažieji“, pasakojimai, kurie atkreipia dèmesį ì tautos ir valstybès istorijų „paraštėse“ likusius lokalius, kasdienius, nesenos ir neherojinės praeities fragmentus. Šiais pasakojimais nekuriami visa apimantys, alternatyvūs istorijos ir kultūros vaizdiniai, tačiau jų koegzistavimas, tikètina, formuoja / išreiškia ịvairialypiškesnès, prieštaringesnès, sudètingesnès, dinamiškesnès praeities suvokimą. Dèmesys temoms ir kontekstams alternatyviuose muziejiniuose pasakojimuose nurodo jų orientaciją link moderniems muziejams priskirtų prieigų.

Gauta 20120412 Priimta 20120426

\section{Šaltiniai ir literatūra}

[1] ANDERSON, David. Case Study: Developing Historical Thinking Through an Interactive Gallery. In: Developing Museum Exhibitions for Lifelong Learning. Ed. G. Durbin. London: The Stationery Office, 1996, p. 163-169.

[2] BRAUDEL, Fernand. Kapitalizmo dinamika. Iš prancūzų k. vertè A. Nastopkaitè. Vilnius: Baltos lankos, 1994.

[3] BŪČYS, Žygintas. Rinkinių valdymas: formavimas ir dokumentavimas. Iš: Muzieju vadyba. Seminarai, teorija, praktika. Sudarè V. Liutkus. Vilnius: Lietuvos kultūros darbuotojų tobulinimosi centras, 2002, p. 46-53.

[4] BŪČYS, Žygintas. Šiuolaikinè nacionalinio muziejaus samprata bei naujo muziejaus kūrimo galimybès Lietuvoje. Iš: Muziejiniai Vilniaus istorijos kontekstai. Mokslinių straipsnių rinkinys. Sudarė N. Keršytè. Vilnius: Kultūros, filosofijos ir meno institutas, 2008, p. 58-64.

[5] BUMBLAUSKAS, Alfredas; ČEPAITIENĖ, Rasa; POŠKIENĖ, Justina; ŠERMUKŠNYTE், Rūta; VAŠTOKAS, Romas. Lietuvos Didžiosios Kunigaikštystès Valdovų rūmų atkūrimo ir paskirties koncepcijos plètros gairès (2002 m.). Iš: Lietuvos Didžiosios Kunigaikštystès Valdovų rūmų atkūrimo byla. Vieno požiūrio likimas. Sudarè A. Bumblauskas, S. Kulevičius. Vilnius: Vilniaus universiteto l-kla, 2006, p. 35-71.

[6] CARNEGIE, Elizabeth. Trying to Be an Honest Woman: Making Women's Histories. In: Making Histories in Museums. Ed. G. Kavanagh. London and New York: Leicester University Press, 1999 , p. 54-65.

[7] CLIFFORD, James. Kultūros problema. XX amžiaus etnografija, literatūra ir menas. Iš anglų k. vertė V. Šarkovas. Vilnius: Lietuvos rašytojų sąungos 1-kla, 2006.

[8] ČEPAITIENĖ, Rasa. Homo sovieticus muziejaus projektas - atvira erdvė sovietmečio vertinimams. Iš: Muziejiniai Vilniaus istorijos kontekstai. Mokslinių straipsnių rinkinys. Sudarè N. Keršytė. Vilnius: Kultūros, filosofijos ir meno institutas, 2008, p. 44-57. 
[9] FITZERALD, Lawrence. Hard Men, Hard Facts and Heavy Metal: Making Histories of Technology. In: Making Histories in Museums. Ed. G. Kavanagh. London, New York: Leicester University Press, 1999, p. 116-130.

[10] Gyvosios istorijos programa: istorinè kultūra šiuolaikinès sąmonès formavimui. Pagr. teksto autorius A. Bumblauskas. Vilnius: Kultūros paveldo institutas, 1998.

[11] GLUZIŃSKI, Wojcech. U podstaw muzeologii. Warszawa: Państwowe Wydawnictwo Naukowe, 1980 .

[12] GODAU, Sigrid. Inszenisierung oder Rekonstruktion? Zur Darstellung von Geschichte im Museum. In: Geschichte, Bild, Museum. Zur Darstellung von Geschichte im Museum. Hg. M. Fehr, S. Grohe. Köln: Wienand Verlag, 1989, S. 199-211.

[13] HERLES, Diethard. Das Museum und die Dinge. Wissenschaft. Präsentation. Pädagogik Frankfurt, New York: Campus Verlag, 1996.

[14] HOEKSTRA, Henk. Audiovisuelle Sprache und Kultur - Moralische Bildung. In: Neue Medien - Mehr Verantwortung! Hg. F. Schmälzle. 1996, S. 86-89.

[15] KAVANAGH, Gaynor. Dream Spaces: Memory and the Museum. London and New York: Leicester University Press, 2000.

[16] KAVANAGH, Gaynor. History Curatorship. London: Leicester University Press, 1990.

[17] KERŠYTÉ, Nastazija. Lietuvos muziejai iki 1940 metų. Vilnius: Lietuvos nacionalinis muziejus, 2003.

[18] KERŠYTĖ, Nastazija. Lietuvos muziejai. Pokyčiai ir tęstinumas. Mokomoji knyga. Vilnius: Vilniaus universitetas, 2007.

[19] KERŠYTĖ, Nastazija. Muzeologija Lietuvos mokslo kontekste. Knygotyra, 2003, Nr. 40, p. 1023.

[20] KERŠYTĖ, Nastazija. Muziejiniai Vilniaus istorijos kontekstai. Iš: Muziejiniai Vilniaus istorijos kontekstai. Mokslinių straipsnių rinkinys. Sudarẻ N. Keršytė. Vilnius: Kultūros, filosofijos ir meno institutas, 2008, p. 9-25.

[21] KORFF, Gotfried; ROTH, Martin. Vorwort. In: Das historische Museum. Labor, Schaubühne, Identitätsfabrik. Hg. G. Korff, M. Roth. Frankfurt am Main: Campus Verlag, 1990, S. 7-8.

[22] KOS, Wolfgang. Redefining the Mission: from the Historical Museum of the City of Vienna to the Wien Museum. Iš: Muziejiniai Vilniaus istorijos kontekstai. Mokslinių straipsnių rinkinys. Sudare N. Keršyte. Vilnius: Kultūros, filosofijos ir meno institutas, 2008, p. 126-135.

[23] Kryžiaus karų epocha Baltijos regiono tautu istorinèje sąmonèje. Mokslinių straipsnių rinkinys. Sudare R. R. Trimoniené, R. Jurgaitis. Šiauliai: Saulès delta, 2007.

[24] LR Seimo nutarimas Nr. XI-797 „Dèl 2012 metų paskelbimo muziejų metais“. 2010 m. balandžio 29 d. [žiūrèta 201201 14]. Prieiga per internetą: <http://www3.lrs.lt/pls/inter3/dokpaieska. showdoc_l?p_id=371176>.

[25] LUBYTĖ, Elona. Bendradarbiavimo galia: „Moters laikas. Skulptūra ir kinas“ Nacionalinèje dailès galerijoje sumanymo ir igyvendinimo patirtys. Iš: Lietuvos dailès muziejus. Metraštis, 2011, Nr. 14(2010), p. 72-88. [žiūreta 201203 14]. Prieiga per internetą: <http://www.ldm.lt/LDM/LDM_ metrastis_14.htm >.

[26] MAČIULIS, Dangiras. Laikinosios sostinès kolektyvinès atminties kraštovaizdis. Iš: Nuo Basanavičiaus, Vytauto Didžiojo iki Molotovo ir Ribbentropo: atminties ir atminimo kultūru transformacijos XX-XXI amžiuje. Straipsnių rinkinys. Sudare A. Nikžentaitis. Vilnius: Lietuvos istorijos instituto l-kla, 2011, p. 133-156.

[27] Making Histories in Museums. Ed. G. Kavanagh. London and New York: Leicester University Press, 1999. 
[28] MICHELKEVIČIUS, Vytautas. Tarpdisciplininès komunikacijos mokslų transformacijos vokiškoje mokslo tradicijoje: medijų paradigma. Informacijos mokslai, 2006, Nr. 37, p. 135-143.

[29] Naujasis Vilniaus perskaitymas: Didieji Lietuvos istoriniai pasakojimai ir daugiakultüris miesto paveldas. Straipsnių rinktinè. Sudare A. Bumblauskas. Vilnius: Vilniaus universiteto l-kla, 2009.

[30] NIKŽENTAITIS, Alvydas. Atminties ir atminimo kultūrų modeliai: Lietuva, Lenkija, Rusija, Vokietija. Iš: Nuo Basanavičiaus, Vytauto Didžiojo iki Molotovo ir Ribbentropo: atminties ir atminimo kultūru transformacijos XX-XXI amžiuje. Straipsnių rinkinys. Sudarẻ A. Nikžentaitis. Vilnius: Lietuvos istorijos instituto 1-kla, 2011, p. 439-458.

[31] NORKUS, Zenonas. Jörno Rüseno istorinès kultūros studijų teorinès idejjos. Problemos, 2005, t. 67, p. $33-47$.

[32] Nuo Basanavičiaus, Vytauto Didžiojo iki Molotovo ir Ribbentropo: atminties ir atminimo kultūru transformacijos XX-XXI amžiuje. Straipsnių rinkinys. Sudarè A. Nikžentaitis. Vilnius: Lietuvos istorijos instituto 1-kla, 2011.

[33] RESE, Bernd. Didaktik im Museum: Systematisierung und Neubestimmung. Bonn: Dr. Rudolf Habelt GmbH, 1995.

[34] RÜSEN, Jörn. Kas yra istorijos kultūra? Samprotavimai apie naują būdą, kaip apmąstyti istoriją. Ǐs: J. Rüsen. Istorika. Istorikos darbų rinktinè. Sudarẻ Z. Norkus, iš vokiečių k. vertẻ A. Jankauskas. Vilnius: Margi raštai, 2007, p. 78-108.

[35] RÜSEN, Jörn. Tarpkultūrinè komunikacija. Etnocentrizmo iššūkiai ir kultūros mokslų atsakymas. Iš: J. Rüsen. Istorika. Istorikos darbų rinktinė. Sudarẻ Z. Norkus, iš vokiečiu k. vertė A. Jankauskas. Vilnius: Margi raštai, 2007, p. 261-286.

[36] SAFRONOVAS, Vasilijus. Lietuvos atminimo politikos tendencijos po 1990 metų. Iš: Nuo Basanavičiaus, Vytauto Didžiojo iki Molotovo ir Ribbentropo: atminties ir atminimo kultūru transformacijos XX-XXI amžiuje. Straipsnių rinkinys. Sudare A. Nikžentaitis. Vilnius: Lietuvos istorijos instituto 1-kla, 2011, p. 337-378.

[37] SALATKIENE, Birutè. Kryžiaus karų epochos ịvaizdis Lietuvos muziejų ekspozicijose. Iš: Kryžiaus karu epocha Baltijos regiono tautu istorinèje sąmonèje. Mokslinių straipsnių rinkinys. Sudarè R. R. Trimonienè, R. Jurgaitis. Šiauliai: Saulès delta, 2007, p. 263-277.

[38] SCHMIDT-SINNS, Dieter. Zeitgeschichte im Bild nach vier Jahrzenten. In: Das Fernsehen als Vermittler von Geschichtsbewusstsein. Hg. W. Becker, S. Quandt. Bonn: Bundeszentrale für politische Bildung, 1991, S. 9-13.

[39] SVERDIOLAS, Arūnas. Apie paméklinę būtį. Vilnius: Baltos lankos, 2006.

[40] ŠERMUKŠNYTĖ, Rūta. Istorija, muziejus ir didaktine perteikimo problema. Metodinè priemonè. Vilnius: Vilniaus universiteto l-kla, 2008.

[41] ŠUTINIENÉ, Irena. Daugiakultūrio miesto istorija komunikacinèje tautinių grupių atmintyje: Klaipedos ir Vilniaus atvejai. Iš: Nuo Basanavičiaus, Vytauto Didžiojo iki Molotovo ir Ribbentropo: atminties ir atminimo kultūrų transformacijos XX-XXI amžiuje. Straipsnių rinkinys. Sudarè A Nikžentaitis. Vilnius: Lietuvos istorijos instituto l-kla, 2011, p. 225-284.

[42] ŠUTINIENE, Irena. Lietuvos Didžiosios Kunigaikštystės paveldo reikšmès populiariosiose tautinio naratyvo interpretacijose. Lietuvos istorijos studijos, 2008, t. 21, p. 102-120.

[43] ŠUTINIENÉ, Irena. Tautos istorijos simboliai Lietuvos gyventojų tautinejje vaizduoteje: herojų ìvaizdžiai ir jų kaita. Sociologija. Mintis ir veiksmas, 2009, Nr. 1(24), p. 40-62.

[44] WAIDACHER, Friedrich. Bendrosios muzeologijos metmenys. Iš vokiečių k. vertė A. Tekorius. Vilnius: Lietuvos nacionalinis muziejus, 2007.

[45] WALLACE, Michael. The Future of History Museums. In: Museum Provision and Professionalism. Ed. G. Kavanagh. London and New York: Routledge, 2005, p. 69-78. 
[46] ZIĘBIŃSKA-WITEK, Anna. Wizualizacje pamięci - upamiętnianie Zagłądy w muzeach [žiūrèta 201201 14]. Prieiga per internetą: <http://jazon.hist.uj.edu.pl/zjazd/referaty.htm>.

[47] КИНАРД, Джон. Музей как ускоритель общественного прогресса. Museum (Ежеквартальный журнал Юнеско), 1985, №. 148, с. 37-43.

[48] ХАЛПИН, Марджори. „Сыграй это снова, Сэм“: размышления о новой музеологий. Museum (Ежеквартальный журнал Юнеско), 1997, №. 194, с. 52-57.

[49] ШОУТЕН, Франс. Просветительная работа в музеях - предмет постоянной заботы. Museum (Ежеквартальный журнал Юнеско), 1988, №. 156, с. 27-30.

[50] ЮРЕНЕВА, Тамара Юрьевна. Музееведение. Учебник для высшей школы. Москва: Академический Проект, 2003.

RŪTA ŠERMUKŠNYTÉ

\title{
Historical Museum: The concept, ideas for creating narratives for modern museums, and their manifestation in the City of Vilnius
}

\author{
Summary
}

The article attempts to bring to the fore an issue left on the margins of historical culture / memory studies enjoying a resurgence in Lithuania: what kind of historical and cultural orientation does the Historical Museum present in its narratives? The question posed by its nature leads to the double nature of this study: the orientation towards generalities and towards analysis of the specific instance. Museum researches from abroad and by Lithuanians are employed to define the changing concept of the Historical Museum, to reveal the characteristics of the Historical Museum as a form of historical culture and to explain the ideas behind the creation of current museum narratives. Based on this research, a study of the history of museum narratives in Vilnius is conducted. Vilnius is a good candidate for such kind of research because it is the city in Lithuania with the most developed network of museums, which in turn means it has the greatest diversity in museum narratives. The study, based on analysis of exhibits in the museums of this city which have recently been put on display or are still running, is oriented toward illustration of basic trends (dominant and alternative) rather than explicating all possible variations of museum narratives.

Key words: Historical Museum, historical consciousness, historical culture, museum narrative, Vilnius 